\title{
Faktor Prognosis Terjadinya Syok pada Demam Berdarah Dengue
}

\author{
Raihan, * Sri Rezeki S Hadinegoro, ** Alan R Tumbelaka** \\ *Divisi Infeksi dan Penyakit Tropis SMF/Departemen Ilmu Kesehatan Anak, FK Universitas Syiah Kuala/ \\ RSU Dr. Zainoel Abidin Banda Aceh \\ ** Divisi Infeksi dan Penyakit Tropis SMF, Departemen Ilmu Kesehatan Anak, FK Universitas Indonesia/ \\ RSUP Dr. Cipto Mangunkusumo Jakarta
}

Latar belakang. Infeksi virus dengue hingga saat ini masih menjadi masalah kesehatan di Indonesia. Mengingat manifestasi klinis yang sangat bervariasi, diagnosis klinis awal demam berdarah dengue (DBD) sering sulit ditegakkan, apalagi untuk memprediksi apakah seorang pasien akan menjadi syok atau syok berulang. Penilaian akurat terhadap risiko syok merupakan kunci penting menuju tatalaksana yang adekuat, mencegah syok, dan perdarahan.

Tujuan. Mencari parameter klinis dan laboratoriss sebagai faktor resiko terjadinya syok pada pasien DBD.

Metode. Penelitian retrospektif dengan menggunakan data rekam medik pasien DBD yang memenuhi kriteria WHO 1997 dan dikonfirmasi dengan pemeriksaan serologi di Bagian Ilmu Kesehatan Anak RSUP Dr Cipto Mangunkusumo Jakarta dari Januari 2007-Desember 2009. Variabel independen adalah lama demam, perdarahan, hepatomegali, hemokonsentrasi, leukosit, trombosit. Faktor prognosis syok merupakan variabel dependen. Analisis dengan menggunakan analisis regresi logistik

Hasil. Dari 276 pasien yang memenuhi kriteria penelitian, 139 di antaranya (50,3\%) perempuan dan 137 $(49,6 \%)$ laki-laki dengan usia 5-10 tahun sebagai kelompok terbanyak. Lebih separuh pasien $(69,2 \%)$ mempunyai gizi baik. Syok terjadi pada 103 (37,3\%) pasien terutama pada hari keempat sakit (81,6\%). Hepatomegali ditemukan pada 49,6\% kasus, perdarahan saluran cerna 14,9\%, hemokonsentrasi $81,2 \%$, kadar hematokrit $\geq 42 \% 54,3 \%$. leukosit $<5.000 / \mathrm{mm}^{3} 76,8 \%$ dan jumlah trombosit $\geq 50.000-100.000 / \mathrm{mm}^{3}$ 67,4\%. Hasil analisis regresi logistik menunjukkan hepatomegali dan perdarahan saluran cerna adalah faktor prognosis yang paling berperan terhadap terjadinya syok dengan AOR berturut-turut 13,8 dan 8,4.

Kesimpulan. Karakteristik klinis yaitu hepatomegali dan perdarahan saluran cerna merupakan faktor prognosis terjadinya syok pada DBD. (Sari Pediatri 2010;12(1):47-52).

Kata kunci: demam berdarah dengue, syok, faktor prognosis

Alamat korespondensi:

Dr. Raihan, Sp.A, Divisi Infeksi dan Pediatri Tropis, Universitas Syah Kuala/RSU Dr. Zainal Abidin, Banda Aceh

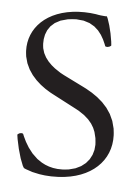

ejak pertama kali ditemukan pada tahun 1968 hingga kini infeksi virus dengue menunjukkan peningkatan insidens. ${ }^{1}$ Angka kesakitan penyakit demam berdarah dengue (DBD) 
cenderung meningkat dari tahun ke tahun, walaupun demikian angka kematian secara nasional cenderung menurun dari 41,4\% pada tahun 1968 menjadi 4\% pada tahun 1980, 1,4\% pada tahun 2000 dan hanya $0,9 \%$ pada tahun 2001. Namun angka kematian akibat dengue syok sindrom (DSS) yang disertai dengan perdarahan gastrointestinal hebat dan ensefalopati masih tetap tinggi. ${ }^{2}$ Rampengan pada tahun 1986 melaporkan kejadian syok di Manado berkisar 60\% dari seluruh pasien DBD dengan angka kematian 6,6\%. Sedangkan Hadinegoro ${ }^{4}$ mendapatkan prevalensi syok 16\%-40\% pada hampir di seluruh rumah sakit di Indonesia dengan angka kematian 5,7\%-50\% pada tahun 1996.

Patogenesis utama yang menyebabkan kematian pada hampir seluruh pasien DBD adalah syok karena kebocoran plasma. Penanganan yang tepat dan sedini mungkin terhadap pasien presyok dan syok merupakan faktor penting yang menentukan hasil pengobatan. Oleh karena itu penilaian yang akurat terhadap risiko syok merupakan kunci penting menuju tatalaksana yang adekuat, mencegah syok, dan perdarahan. ${ }^{5}$

World Health Organization merekomendasikan kriteria diagnosis DBD berdasarkan klinis maupun laboratoris yang menjadi acuan para klinisi dalam membantu menegakkan diagnosis dan klasifikasinya. ${ }^{5}$ Namun dengan manifestasi klinis yang sangat bervariasi, patogenesis yang kompleks, dan perbedaan serotipe virus pada daerah yang berbeda, membuat kita sulit memprediksi perjalanan penyakit DBD apalagi dalam menilai apakah pasien akan menjadi syok atau syok berulang. Perlunya antisipasi dini terhadap syok telah menggugah keingintahuan peneliti untuk mencari faktor prognosis terjadinya syok pada anak.

\section{Metode}

Penelitian yang kami lakukan merupakan studi retrospektif yang mengukur parameter klinis (lama demam, hepatomegali, perdarahan) dan laboratoris (hemokonsentrasi, jumlah leukosit, jumlah trombosit) pada pasien DSS yang dirawat dari Januari 2007 hingga Desember 2009. Data diambil dari rekam medik Departemen Ilmu Kesehatan Anak RSUP Dr. Cipto Mangunkusumo Jakarta. Kriteria inklusi adalah pasien DBD usia 0-18 tahun yang memenuhi kriteria WHO 1997 dengan konfirmasi pemeriksaan serologi IgM dan IgG antidengue positif dan memiliki data rekam medik lengkap. Pasien tidak diikutsertakan apabila mengidap penyakit hematologi atau penyakit infeksi penyerta lain. Variabel dependen adalah syok dengan lama demam, hepatomegali, perdarahan saluran cerna, kadar hematokrit, hemokonsentrasi, jumlah leukosit dan trombosit sebagai variabel independen.

Analisis data dilakukan menggunakan program statistik SPSS versi 11,5. Regresi logistik dipakai untuk mengetahui faktor prognosis terjadinya syok setelah mengontrol faktor-faktor lainnya dengan menggunakan adjusted odds ratio (AOR) dengan $\mathrm{p}<0,05$ adalah bermakna.

\section{Hasil}

Selama Januari 2007-Desember 2009 didapatkan 276 pasien yang memenuhi kriteria penelitian. Usia paling muda adalah 7 bulan dan tertua 17 tahun dengan kelompok usia 5-10 tahun sebagai kelompok yang paling banyak terkena (41\%). Rasio pasien perempuan dan laki-laki relatif sama. Sebagian besar pasien $(69,2 \%)$ mempunyai gizi baik. Delapan puluh persen pasien dirawat setelah mengalami demam tiga hari di rumah atau sakit hari keempat. Hampir separuhnya (49,6\%) mengalami hepatomegali, sedangkan perdarahan saluran cerna terjadi pada 14,9\% kasus (Tabel 1).

Mayoritas pasien $(81,2 \%)$ mengalami hemokonsentrasi pada kadar hematokrit $\geq 42 \%->50 \%$ $(54,3 \%)$. Leukopenia $\left(\leq 5.000 / \mathrm{mm}^{3}\right)$ dijumpai pada $76,8 \%$ kasus dan $67,4 \%$ mempunyai kadar trombosit $50.000-100.000 / \mathrm{mm}^{3}$ (Tabel 2).

Tabel 1. Karakteristik klinis $(\mathrm{n}=276)$

\begin{tabular}{lcc}
\hline Karakteristik & Jumlah & Persentase \\
\hline Umur (tahun) & & \\
$\quad<1$ & 2 & 0,8 \\
$1-<5$ & 52 & 18,9 \\
$5-10$ & 113 & 41 \\
$\quad>10$ & 109 & 39,5 \\
& & \\
Jenis kelamin & & \\
$\quad$ Laki-laki & 137 & 49,6 \\
$\quad$ Perempuan & 139 & 50,3 \\
Status gizi & & \\
$\quad$ Gizi baik & 191 & 69,2 \\
$\quad$ Gizi kurang & 85 & 30,8 \\
Hepatomegali & 137 & 49,6 \\
Perdarahan & 41 & 14,9 \\
\hline
\end{tabular}


Tabel 2. Karakteristik laboratoris $(\mathrm{n}=276)$

\begin{tabular}{lcc}
\hline Karakteristik & Jumlah & Persentase \\
\hline $\begin{array}{l}\text { Hematokrit (\%) } \\
\quad<42\end{array}$ & 126 & 45,7 \\
$\quad 42-45$ & 73 & 26,5 \\
$\quad 46-50$ & 62 & 22,4 \\
$\quad>50$ & 15 & 5,4 \\
& & \\
Hemokonsentrasi $(>20 \%)$ & 224 & 81,2 \\
Leukosit $\left(\mathrm{mm}^{3}\right)$ & & \\
$\quad<5.000$ & 212 & 76,8 \\
$\quad 5.000-10.000$ & 64 & 23,2 \\
Trombosit $\left(\mathrm{mm}^{3}\right)$ & & \\
$\quad<50.000$ & 90 & 32,6 \\
$\quad 50.000-100.000$ & 186 & 67,4 \\
\hline
\end{tabular}

Tabel 3. Parameter klinis sebagai faktor prognosis syok pada DBD

\begin{tabular}{lcc}
\hline Variabel & \multicolumn{2}{c}{$\operatorname{DBD}(\mathrm{n}=276)$} \\
\cline { 2 - 3 } & $\begin{array}{c}\text { Syok } \\
\mathrm{n}(\%)\end{array}$ & $\begin{array}{c}\text { Tanpa syok } \\
\mathrm{n}(\%)\end{array}$ \\
\hline Lama demam (hari) & & \\
3 & $84(30,4)$ & $140(50,7)$ \\
$4-5$ & $16(5,8)$ & $31(11,2)$ \\
$>5$ & $3(1,1)$ & $2(0,7)$ \\
Hepatomegali & $89(32,3)$ & $8(17,4)$ \\
Perdarahan saluran cerna & $32(11,6)$ & $9(3,3)$ \\
\hline
\end{tabular}

Tabel 4. Parameter laboratoris sebagai faktor prognosis syok pada DBD

\begin{tabular}{lcc}
\hline Variabel & \multicolumn{2}{c}{ DBD $(\mathrm{n}=276)$} \\
\cline { 2 - 3 } & $\begin{array}{c}\text { Syok } \\
\mathrm{n}(\%)\end{array}$ & $\begin{array}{c}\text { Tanpa syok } \\
\mathrm{n}(\%)\end{array}$ \\
\hline $\begin{array}{l}\text { Hemokonsentrasi }(\geq 20 \%) \\
\text { Leukosit }\left(\mathrm{mm}^{3}\right)\end{array}$ & $90(32,6)$ & $134(48,6)$ \\
$\quad<5.000$ & $73(26,5)$ & $139(50,4)$ \\
$\quad 5.000-10.000$ & $30(10,9)$ & $34(12,3)$ \\
Trombosit $\left(\mathrm{mm}^{3}\right)$ & & \\
$\quad<50.000$ & $41(14,9)$ & $49(17,8)$ \\
$50.000-100.000$ & $62(22,5)$ & $124(44,9)$ \\
\hline
\end{tabular}

Dari 103 (37,3\%) pasien yang mengalami syok, hepatomegali ditemukan pada $32,3 \%$ pasien dan perdarahan saluran cerna $11,6 \%$. Sebagian besar pasien mengalami syok pada hari ke-4 (30,4\%), dengan hemokonsentrasi $\geq 20 \%$ pada $32,6 \%$ kasus. Pada saat syok jumlah leukosit sebagian besar pasien $(26,5 \%)$ masih $<5.000 / \mathrm{mm}^{3}$ dengan $22,5 \%$ mempunyai kadar trombosit $\geq 50.000-100.000 / \mathrm{mm}^{3}$ (Tabel 3 dan 4 ).

Hasil analisis regresi logistik memperlihatkan bahwa parameter klinis yang bermakna sebagai faktor prognosis adalah hepatomegali dan perdarahan saluran cerna. Sedangkan dari parameter laboratoris tidak didapatkan satupun parameter yang bermakna sebagai prediktor untuk terjadinya syok (Tabel 5).

\section{Diskusi}

Angka kejadian syok pada penelitian kami 37,3\% seperti yang dilaporkan oleh Gayatri $1997^{6}$ di Jakarta, $37,6 \%$. Sedangkan penelitian lain melaporkan, Kan $(2004)^{7}$ di Manado 47\%, Shah $(2005)^{8}$ di Mumbai $41,2 \%$ dan Dewi dkk (2006) ${ }^{9}$ di RSCM 58\%. Dibandingkan dengan hasil yang diperoleh Thu dkk, ${ }^{10}$ Kanath dkk, ${ }^{11}$ dan Malavige dkk ${ }^{12}$ (20\%, 16,4\%, dan $33,7 \%$ ) angka kejadian syok pada penelitian kami lebih tinggi. Hasil ini masih sesuai dengan prevalensi syok yang didapatkan Hadinegoro ${ }^{4}$ pada hampir seluruh rumah sakit yang ada di Indonesia yaitu 16\%-40\%. Kejadian syok yang lebih tinggi pada penelitian Kan dan Dewi kemungkinan disebabkan pada saat tersebut sedang terjadi KLB DBD.

Kelompok usia 5-10 tahun merupakan kelompok yang paling banyak terinfeksi virus dengue. Berbeda dengan penelitian Rampengan ${ }^{3}$ yang melaporkan kelompok usia yang lebih muda (4-6 tahun), sedangkan $\mathrm{Kan}^{7}$ dan Dewi $\mathrm{dkk}^{9}$ menemukan hasil

Tabel 5. Analisis regresi logistik faktor prognosis syok pada DBD

\begin{tabular}{lcccc}
\hline Variabel & $\begin{array}{c}\text { Coefficient } \\
(\mathrm{b})\end{array}$ & $\begin{array}{c}\text { Standard Error } \\
(\mathrm{SE})\end{array}$ & $\begin{array}{c}\text { Sig } \\
(\mathrm{p})\end{array}$ & $\begin{array}{c}\text { Exp } \\
(\mathrm{B})\end{array}$ \\
\hline Lama demam & 0,308 & 0,388 & 0,426 & 1,4 \\
Hepatomegali & 2,262 & 0,371 & $0,000^{*}$ & 13,8 \\
Perdarahan saluran cerna & 2,132 & 0,517 & $0,000^{*}$ & 8,4 \\
Hemokonsentrasi & 0,644 & 0,505 & 0,202 & 1,9 \\
Leukosit & $-0,056$ & 0,394 & 0,887 & 0,9 \\
Trombositopenia & $-0,158$ & 0,310 & 0,611 & 0,8 \\
Konstanta & $-2,762$ & 1,812 & 0,127 & 0,6 \\
\hline
\end{tabular}

${ }^{*} \mathrm{p}<0,05$ 
yang hampir sama dengan peneltian ini (5-9 tahun dan 6-10 tahun). Pada umumnya pasien DBD berusia di bawah 15 tahun, terbanyak di bawah 10 tahun, memiliki derajat keparahan yang cenderung lebih tinggi. Makin muda usia pasien, makin tinggi pula mortalitasnya. ${ }^{5}$ Peneliti lain mendapatkan bahwa kerentanan untuk terjadi syok relatif konstan antara umur 4 sampai 12 tahun dan menurun pada usia remaja. Hal ini kemungkinan disebabkan karena pada anak yang lebih muda endotel pembuluh darah kapiler lebih rentan terjadi pelepasan sitokin sehingga terjadi peningkatan permeabilitas kapiler. ${ }^{13}$ Selain itu perbedaan ini kemungkinan disebabkan karena terjadinya perubahan pola transmisi. Pada awal era DBD transmisi umumnya terjadi di rumah namun saat ini telah beralih ke fasilitas publik seperti sekolah, mesjid, gereja dan tempat bermain anak-anak. ${ }^{14} \mathrm{Hal}$ ini didukung oleh hasil penelitian Soegijanto $\mathrm{dkk}^{15}$ yang menemukan $72 \%$ pasien yang dirawat di rumah sakit adalah anak sekolah dan hanya $28 \%$ yang berusia di bawah 5 tahun.

Prevalensi berdasarkan jenis kelamin tidak didapatkan perbedaan rasio antara perempuan dan laki-laki. Perbandingan ini sama dengan yang diperoleh Lubis $^{16}$ di Medan tapi berbeda dengan Gayatri ${ }^{6}(1,3: 1)$, Dewi $\mathrm{dkk}^{9}(1,1: 1)$, dan $\operatorname{Kan}^{7}$ (1,4:1). Halstead (2004) menyatakan bahwa insidens infeksi virus dengue di daerah endemik identik antara anak laki-laki dan perempuan. ${ }^{17}$

Dengue syok sindrom lebih sering terjadi pada anak imunokompeten dan status gizi baik, sangat jarang pada malnutrisi. Status gizi baik berhubungan dengan respon imun yang baik yang dapat menimbulkan DBD berat. ${ }^{17}$ Penelitian kami menunjukkan hasil yang mendukung teori tersebut. Sedangkan Maron dkk, ${ }^{18}$ Malavige dkk, ${ }^{12}$ Dewi dkk, ${ }^{9}$ dan Tantracheewatron $(2007)^{19}$ tidak mendapatkan perbedaan bermakna antara status gizi baik dan gizi kurang.

Lama sakit menentukan perjalanan penyakit DBD berada pada suatu fase dari tiga fase yang ada yaitu fase demam (hari sakit ke 1-3), fase kritis/syok (hari sakit ke 4-7), atau fase penyembuhan (hari sakit lebih dari 7). ${ }^{4}$ Pasien DBD yang tidak mengalami syok cenderung datang berobat lebih awal dibandingkan dengan mereka yang mengalami syok. ${ }^{13}$ Sebagian besar pasien dalam penelitian kami masuk rumah sakit pada hari keempat setelah tiga hari mengalami demam, sama seperti yang dilaporkan Rampengan (1992). ${ }^{20}$ Penelitian Soedarmo pada 230 anak yang mengalami syok mendapatkan anak telah mengalami demam 3 , 4, 5, dan 6 hari berturut-turut $28,3 \%, 27,8 \%, 33,9 \%$, dan $10 \% .{ }^{13}$ Hadinegoro $\mathrm{dkk}^{4}$ menyatakan bahwa fase syok terjadi pada hari sakit ke 4-7, kebocoran plasma terhebat terjadi setelah demam tiga hari dan berlangsung selama 24-48 jam. Namun lama demam di rumah kadang-kadang tidak tepat diketahui karena penentuan lama demam berdasarkan anamnesis dari orangtua.

Hepatomegali sebagai salah satu patokan WHO untuk diagnosis DBD dilaporkan sangat bervariasi. Penemuan klinis ini tidak secara konsisten ditemukan. Beberapa peneliti berpendapat bahwa mungkin hepatomegali berkaitan dengan galur dan serotipe virus. Kami mendapatkan hepatomegali pada 86\% pasien DSS, hampir sama dengan penelitian di RSCM sebelumnya oleh Dewi dkk (85\%). ${ }^{9}$ Sedangkan Djoharman $^{21}$ dan $\operatorname{Kan}^{7}$ menemukan pada 27\% dan $76,2 \%$ kasus DSS. Hepatomegali harus selalu "dicari" (diraba) selama perjalanan penyakit bukan hanya pada saat masuk rumah sakit. Dari analisis regresi logistik hepatomegali merupakan faktor prognosis terjadinya syok pada DBD.

Perdarahan saluran cerna merupakan salah satu komplikasi yang ditakutkan. ${ }^{4}$ Angka kejadian perdarahan saluran cerna pada penelitian kami lebih banyak ditemukan pada DSS. Dari analisis regresi logistik diperoleh hasil bahwa perdarahan saluran cerna merupakan faktor prognosis terjadinya syok pada DBD. Kondisi ini dapat dijelaskan karena perdarahan yang timbul akan memperberat kehilangan volume plasma akibat kebocoran sehingga mempercepat terjadinya syok. Tantracheewatrohn ${ }^{19}$ juga mendapatkan hasil serupa dan menyatakan bahwa perdarahan merupakan salah satu prognosis terjadinya syok dengan AOR 5,1 meskipun tidak membedakan asal perdarahan apakah dari mukosa atau dari saluran cerna. ${ }^{19}$

Pada penelitian kami sebagian besar pasien mengalami hemokonsentrasi dengan lebih separuhnya mempunyai kadar hematokrit $\geq 42 \%$-> $50 \%$. Dewi $\mathrm{dkk}^{9}$ dan $\mathrm{Kan}^{7}$ mendapatkan nilai hematokrit 46\%$50 \%$ yang terbanyak mengalami syok, sedangkan Gayatri ${ }^{6}$ 40\%-45\%. Nilai hematokrit yang tinggi diasosiasikan dengan kebocoran plasma. Makin besar kebocoran yang terjadi makin tinggi nilai hematokritnya. Kebocoran plasma ini mencapai puncaknya pada saat syok. Hemokonsentrasi yang ditandai dengan peningkatan hematokrit $20 \%$ atau 
lebih mencerminkan peningkatan permeabilitas kapiler, perembesan plasma dan berhubungan dengan beratnya penyakit. ${ }^{4}$ Hemokonsentrasi dengan peningkatan hematokrit $20 \%$ atau lebih dianggap menjadi bukti definitif adanya peningkatan permeabilitas vaskular dan kebocoran plasma. Namun kadar hematokrit juga dipengaruhi oleh penggantian dini volume, intake kurang, loss, dehidrasi, dan perdarahan. ${ }^{4,5}$

Leukopenia sampai lekositosis ringan secara nyata selalu terlihat mendekati akhir fase demam. Limfositosis relatif dengan adanya limfositosis atipikal adalah temuan umum sebelum penurunan suhu atau syok. ${ }^{5}$ Namun peneliti menemukan hasil yang berbeda, pada saat syok lebih banyak ditemukan jumlah leukosit $<5000 / \mathrm{mm}^{3}$.

Penelitian Narayan dkk, ${ }^{22}$ Wichmann $\mathrm{dkk}^{23}$ dan Dewi $\mathrm{dkk}^{9}$ mendapatkan bahwa syok lebih sering terjadi pada trombosit $<50.000 / \mathrm{mm}^{3}$. Dikatakan bahwa jumlah trombosit $<50.000 / \mathrm{mm}^{3}$ harus diwaspadai untuk terjadinya syok karena pada jumlah tersebut telah terjadi gangguan kontinuitas vaskuler yang dapat menyebabkan perdarahan spontan. Namun secara teori juga dikatakan bahwa pada infeksi virus dengue tidak hanya kuantitas trombosit yang terganggu tapi kualitas trombosit juga mengalami masalah. ${ }^{5} \mathrm{Hal}$ ini menjelaskan keadaan meskipun mayoritas pasien dalam penelitian kami mempunyai kadar trombosit $\geq 50.000 / \mathrm{mm}^{3}$, namun angka kejadian perdarahan cukup tinggi.

Analisis regresi logistik menghasilkan bahwa pasien dengan hepatomegali dan perdarahan saluran cerna mempunyai risiko terjadinya syok 13,8 dan 8,4 kali lebih besar. Dewi $\mathrm{dkk}^{9}$ mendapatkan hepatomegali dan jumlah trombosit yang lebih berperan. Sedangkan Tantracheewathorn ${ }^{19}$ melaporkan bahwa hemokonsentrasi $>22 \%$ dan perdarahan; kadar hematokrit, jumlah trombosit, lamanya demam pada penelitian Kan. ${ }^{7}$ Hasil yang bervariasi ini kemungkinan disebabkan oleh besar sampel dan cut off point dari variabel yang berbeda-beda di antara penelitianpenelitian tersebut.

Dengan diketahuinya faktor prognosis, diharapkan para dokter menjadi lebih teliti, waspada dan lebih meningkatkan pemantauan terhadap pasien yang menunjukkan manifestasi klinis hepatomegali dan perdarahan saluran cerna. Keterbatasan pada penelitian kami adalah data berasal dari rekam medik yang sangat bergantung pada kelengkapan data dalam status pasien.

\section{Daftar Pustaka}

1. Soegijanto S, Kushartono H, Hidayah N, Darmowandowo D. Demam berdarah dengue. Dalam Soegijanto $S$, penyunting. Ilmu Penyakit Anak-Diagnosa dan Penatalaksanaan. Jakarta: Salemba Medika; 2002.h.4566.

2. Soedarmo SP. Infeksi virus dengue. Dalam: Soedarmo SP, Garna H, Hadinegoro SRS, penyunting. Buku Ajar Ilmu Kesehatan Anak dan Penyakit Tropis. Edisi pertama. Jakarta: Balai Penerbit Fakultas Kedokteran Universitas Indonesia; 2002.h.176-208.

3. Rampengan TH. Demam berdarah dengue pada anak di RSU Manado. Maj Kedokter Indon 1986;6:300-5.

4. Hadinegoro SRS. Telaah endotoksemia pada perjalanan penyakit demam berdarah dengue: perhatian khusus pada syok, produksi TNF-, interleukin 6 sebagai faktor prediktor demam berdarah dengue berat (disertasi). Jakarta: Fakultas Kedokteran Universitas Indonesia; 1996.

5. WHO. Dengue haemorrhagic fever: diagnosis, treatment and control. Geneva;1997.h.17-27.

6. Gayatri. Faktor-faktor prognosis pada demam berdarah dengue (tesis). Jakarta: Fakultas Kedokteran Universitas Indonesia; 1997.

7. Kan EF, Rampengan TH. Factors associated with shock in children with dengue hemorrhagic fever. Pediatr Indones 2004;44:171-5.

8. Shah I, Katira B. Clinical and laboratory abnormalities due to dengue in hospitalized children in Mumbai. Dengue Bull 2005;29:90-6

9. Dewi R, Tumbelaka AR, Syarif DR. Clinical features of dengue hemorrhagic

fever and risk factors of shock event. Pediatr Indones 2006;46:144-8.

10. Thu MH, Lowry K, Nyuin TT. Myanmar dengue outbreak associated with displacement of serotype 2,3 and 4 by dengue. Diunduh dari http://www.cdc.gov/ incided/EID/vol10No4/03-0216htm. Diakses tanggal $15 \mathrm{Mei}$ 2010.

11. Kanath SR, Rajet S. Clinical feature, complication and atypical manifestation of children with severe form of DHF in South Indian. Ind J Paediatr 2006;73:889-95.

12. Malavige GN, Ranatunga PK, Velathanthiri VGNS. Pattern of disease in Srilanka dengue patients. Arch Dis Child 2006;91:396-400.

13. Soedarmo SP. Masalah demam berdarah dengue di Indonesia. Dalam: Hadinegoro SRS, Satari HI, penyunting. Demam berdarah dengue. Naskah Len- 
gkap. Pelatihan Bagi Pelatih Dokter Spesialis Anak dan Dokter Spesialis Penyakit Dalam Dalam Tatalaksana Kasus DBD. Jakarta: Balai Penerbit Fakultas Kedokteran Universitas Indonesia; 1999.h.1-12.

14. Darmowandowo W. Correlation between humoral immune respons and the severity of dengue hemorrhagic fever. Dalam: Kuntaman, Lusida MI, Hargono R, Poernomo B, penyunting. Proceeding of the International Seminar on Dengue Fever/Dengue Hemorrhagic Fever. Surabaya;1999.

15. Soegijanto S, Darmowandowo W, Basuki PS. Transmission dynamic of dengue hemorrhagic fever in Sawahan Surabaya Indonesia. Dalam: Kuntaman, Lusida MI, Hargono R, Poernomo B, penyunting. Proceeding of the International Seminar on Dengue Fever/Dengue Hemorrhagic Fever. Surabaya;1999.

16. Lubis M. Spectrum of DSS in Haji Adam Malik Hospital during 5 years. Research report from JKPКBPPK. Jakarta:Badan Litbang Kesehatan;2005.h.5-26.

17. Halstead SB. Dengue fever/dengue hemorrhagic fever. Dalam: Behrman RE, Kliegman RM, Arvin AM, penyunting. Nelson textbook of pediatric. Edisi ke-18. Philadelphia: WB Saunders;2007.h.1005-7
18. Maron GM, Clara AW, Diddle JW. Association between nutritional status and severity of dengue infection in children in Salvador. Am J Trop Med Hyg 2001;82:324-9.

19. Tantracheewathorn T, Tantrachewathorn S. Risk factors of dengue shock syndrome in children. J Med Assoc Thai 2007;90:272-7.

20. Rampengan TH. Demam berdarah dengue. Dalam: Rampengan TH, Laurents IR, penyunting. Penyakit infeksi tropik pada anak. Jakarta: EGC; 1992.h.13555

21. Djoharman S, Samsi TK. Demam berdarah dengue berat dengan konfirmasi virologik. Cerm Dunia Kedokter (Edisi khusus) 1992;81:40-3

22. Narayanan M, Aravind MA, Ambikapathy P. Dengue fever-clinical and laboratory parameters associated with complications. Dengue Bull 2003;27:108-15.

23. Wichmann O, Hongsiriwon S, Bowonwatanuwong C, Chotivanich, Sukhtana Y, Pukrittayakamee. Risk factors and clinical features associated with severe dengue infection in adults and children during the 2001 epidemic in Chonburi Thailand. Trop Med and Int Health 2004;9:1022-9. 